\title{
PREMATUR VIDEO SENI DENGAN TEKNIK DUA KANAL
}

\author{
Oleh: Gibbran Prathisara \\ Dosen Ilmu Komunikasi Universitas Ahmad Dahlan \\ E-mail: gibranprathisara@gmail.com
}

\begin{abstract}
:
Creation of works of art as a form of video requires initial idea works. The idea could include objects and nature, events or history, technical process, personal experience or studies. Premature art video works originated from the phenomenon of premature babies due to the smoke of cigarettes smoked by pregnant women or because of exposure to cigarette smoke is inhaled by pregnant women. The phenomenon will be poured in the form of video art works of art that provide information about the effects of hazards and the effects of cigarette smoke is bad for the fetus. Premature art video describes the phenomenon of pregnant women who smoke and are exposed to cigarette smoke that eventually can cause the fetus to be born prematurely. Exposure as to the nature of the video that will be created by using the concept of causality in the system is called the index mark on semiotic. The concept of causality or causal dissected into 2-channel video for presentation. The first video was the cause and the second video into effect. The content of each video is a representation of the phenomenon that is the background of this creation. So from the second video then this will be a concept of causality when combined.
\end{abstract}

Key Words: Video Art, Premature, Smoke.

\begin{abstract}
ABSTRAK:
Penciptaan karya seni video membutuhkan ide sebagai bentuk awal karya. Ide tersebut bisa mencakup benda dan alam, peristiwa atau sejarah, proses teknis, pengalaman pribadi atau kajian. Karya video seni Prematur ini berawal dari fenomena bayi prematur yang disebabkan karena asap rokok yang dihisap oleh ibu hamil atau karena paparan asap rokok yang dihirup oleh ibu hamil. Fenomena tersebut akan dituangkan dalam bentuk karya seni video seni yang memberi informasi tentang akibat dari bahaya dan efek asap rokok yang berdampak buruk bagi janin. Video seni Prematur memaparkan fenomena ibu hamil yang merokok dan terpapar asap rokok yang akhirnya dapat menyebabkan janin lahir prematur. Pemaparan sebagai sifat dari video yang akan dibuat dengan cara menggunakan konsep kausalitas yang dalam sistem tanda pada semiotika disebut indeks. Konsep kausalitas atau sebab akibat dibedah menjadi 2 kanal video untuk penyajiannya. Video yang pertama menjadi sebab dan video kedua menjadi akibat. Konten dari masing-masing video adalah representasi dari fenomena yang menjadi latar belakang penciptaan karya ini. Sehingga dari 2 video ini maka akan menjadi sebuah konsep kausalitas ketika digabung.
\end{abstract}

Kata-kata Kunci: Video Seni, Prematur, Asap Rokok. 


\section{A. PENDAHULUAN}

Penciptaan karya seni berawal dari kebutuhan praktis manusia, didorong oleh kebutuhan untuk menunjang kehidupan sehari-hari, kebutuhan spiritual, hingga kebutuhan hakiki manusia, yakni kebutuhan untuk berkomunikasi dengan sesamanya. Penciptaan seni juga berkaitan erat dengan kebutuhan akan rasa keindahan. Ide, material, peralatan, subjek, objek, dan berbagai unsur lainnya merupakan struktur yang signifikan dan berpengaruh besar dalam bangunan estetika sebuah karya seni. Seni merupakan bentuk dan isi, dimana seni bisa berwujud ide atau gagasan, pengalaman atau tindakan, dan hasil karya manusia atau artefak. Video merupakan cabang seni yang menggabungkan audio dan visual sebagai bentuk satu kesatuan karya. Penciptaan karya seni video tidak jauh berbeda dengan penciptaan karya seni lainnya yang membutuhkan ide sebagai bentuk awal karya. Ide tersebut bisa mencakup benda dan alam, peristiwa atau sejarah, proses teknis, pengalaman pribadi atau kajian.

\section{Latar Belakang Penciptaan Karya}

Merokok merupakan masalah yang masih sulit diselesaikan hingga saat ini. Berbagai dampak dan bahaya merokok sebenarnya sudah dipublikasikan kepada masyarakat, namun kebiasaan merokok masyarakat masih sulit untuk dihentikan. Saat ini konsumsi rokok telah menjadi fenomena yang mendunia, terutama terjadi di negara berkembang yang sebagian besar masyarakatnya adalah masyarakat miskin, dan dari jumlah perokok yang terbanyak berasal dari kelompok masyarakat tersebut. Mereka pula yang memiliki beban ekonomi dan kesehatan yang terberat akibat rokok, dari sekitar 1 milyar perokok di seluruh dunia, $80 \%$ diantaranya di negara-negara berkembang.

"Dampak rokok terhadap kesehatan sering disebut sebagai silent killer karena timbul secara perlahan dalam tempo yang relatif lama, tidak langsung dan tidak nampak secara nyata" (Puryanto, 2012). Sedangkan Aditama menyebutkan bahwa kebiasaan merokok merupakan salah satu penyebab utama penyakit tidak menular diseluruh dunia, antara lain penyakit kardiovaskular, penyakit serebrovaskuler, stroke, jantung, impotensi, berbagai jenis kanker yang disebabkan oleh berbagai bahan kimia atau partikel yang ada di dalam asap rokok tersebut (Aditama, 2004).

Ibu hamil yang terpapar asap rokok akan menambah kemungkinan gangguan kesehatan pada ibu dan janin karena asap rokok yang terhirup pada ibu hamil mengandung zat yang membahayakan seperti karbonmonoksida, dimana karbonmonoksida dapat berdampak buruk pada pernafasan ibu hamil sehingga janin akan kekurangan oksigen (Ross, 2006).

Ibu hamil, suami ibu hamil, dan semua orang perlu menyadari bahwa paparan asap rokok sangat berbahaya bagi kesehatan bayi mereka yang belum lahir. Bahaya asap rokok membahayakan bagi bayi dalam kandungan ibu yang merokok atau ibu hamil yang berada dalam ruangan yang terdapat asap rokok. Bayi dan anak-anak yang terpapar oleh asap rokok orang lain dapat menyebabkan kematian mendadak (sudden infant death syndrome), infeksi saluran pernafasan bawah, asma, dan bronchitis. Biasanya pada ibu 
Diterbitkan oleh Program Studi IImu Komunikasi

Universitas Ahmad Dahlan Yogyakarta

hamil yang merokok dan ibu hamil yang terpapar asap rokok dalam proses kehamilan dapat bermasalah yang termasuk pada bayi berat badan lahir rendah, lahir mati dan lahir cacat. Sehingga efek dari paparan asap rokok pada ibu hamil dapat berpengaruh pada kandungan antara lain seperti bayi lahir prematur.

Sacharin menjelaskan bahwa bayi Prematur adalah bayi yang lahir kurang dari usia kehamilan yang normal (37minggu) dan juga dimana bayi mengalami kelainan penampilan fisik. Prematuritas dan berat lahir rendah biasanya terjadi secara bersamaan, terutama diantara bayi dengan badan 1500 gr atau kurang saat lahir, sehingga keduanya berkaitan dengan terjadinya peningkatan mordibitas dan mortalitas neonatus dan sering di anggap sebagai periode kehamilan pendek (Sacharin 1996).

Masalah kesehatan pada bayi prematur, membutuhkan asuhan keperawatan, dimana pada bayi prematur sebaiknya dirawat di rumah sakit karena masih membutuhkan cairan -cairan dan pengobatan serta pemeriksaan Laboratorium yang tidak semua Rumah Sakit mempunyai fasilitas yang memadai untuk merawat bayi prematur, sehingga banyak kasus bayi prematur yang tidak selamat karena faktor minimnya fasilitas dan perawatan.

Terlepas dari hal itu yang harus disadari adalah salah satu faktor penyebab bayi prematur adalah Ibu yang merokok dan juga Ibu hamil yang terkena paparan asap rokok. Linda menyebutkan adapun pengaruh paparan asap rokok dari orang lain sangat berbahaya karena $75 \%$ asap rokok akan terhirup pada ibu hamil atau dikatakan dengan perokok pasif sehingga ibu hamil dapat dikatakan resiko tinggi terpapar asap rokok yang menimbulkan efek ibu hamil menjadi faktor bahaya bagi janin (Linda, 2011).

Dari fenomena yang terjadi dan pendalaman data-data terkait kasus diatas, penciptaan karya ini mengangkat tema premature dengan objek figure bayi yang akan dijadikan subyek matter (pokok bahasan), dan sekaligus sebagai wujud ekspresi, eksplorasi serta respon terhadap situasi yang sedang terjadi saat ini.

\section{Rumusan Ide Penciptaan}

"Ide merupakan rencana yang tersusun dalam pikiran, gagasan dan cita- cita" (Santoso Ananda, 2000 : 141). Jadi ide merupakan daya penggerak dari proses penciptaan karya seni, sebagai langkah untuk melahirkan suatu karya baru, ide atau gagasan muncul apabila didasari oleh konsep dalam penciptaan. Bila ditinjau dari arti kata konsep merupakan pokok pertama yang mendasari seluruh pemikiran.

Ide penciptaan dari karya ini berawal dari fenomena bayi prematur yang disebabkan karena asap rokok yang dihisap oleh ibu hamil atau karena paparan asap rokok yang dihirup oleh ibu hamil. Fenomena tersebut akan dituangkan dalam bentuk karya seni video seni yang memberi informasi tentang akibat dari bahaya dan efek asap rokok yang berdampak buruk bagi janin. Karya seni ini nantinya akan berbentuk video seni yang menggunakan konsep kausal sebagai pola ungkap pesan. Konten dari video seni ini adalah fenomena ibu hamil yang merokok dan terpapar asap rokok sehingga mengakibatkan janin lahir secara prematur. Penyajian karya dengan menggunakan dua kanal akan menjadi teknik untuk mengaplikasikan konsep kausal. Dua video dengan konten yang berbeda dan diputar dalam waktu bersamaan menggunakan dua layar yang 
ditata atas dan bawah. Dari dua video ini akan menjadi satu kesatuan yang membentuk pesan secara utuh.

Permasalahan yang berusaha dijawab melalui video seni "Prematur" ini adalah bagaimana menciptakan sebuah karya untuk menyampaikan fenomena dan pesan secara halus menggunakan proses semiologi dengan tanda indeksikal dalam bentuk audiovisual sehingga timbul sebuah kesadaran atau pola pikir baru dari masyarakat. Penyajian karya dengan dua kanal sebagai strategi pola ungkap dalam karya dan sebagai medium untuk mengaplikasikan konsep indeksikal.

\section{Orisinalitas}

Seperti yang disampaikan Jacob Sumardjo dalam buku Filsafat Seni bahwa "Karya seni merupakan totalitas ekspresi yang bersifat individual, setiap karya seni menunjukan jati diri dan sikap kesenimannya" (Jacob, 2000). Dengan mengacu pada referensi ide dan tema yang sejenis dari karya yang sudah ada kemudian mengembangkannya, secara tidak langsung mengasah kemampuan untuk menciptakan sesuatu yang kreatif dan inovatif. Sebuah karya bisa jadi memiliki tema yang sama dengan karya lainnya, namun tampilan karya tersebut pasti berbeda. Orisinalitas sebuah karya mencerminkan kreativitas dan kekuatan daya cipta senimannya. Secara tematik penulis menemukan banyak karya video yang menjadikan rokok sebagai tema. Penciptaan karya "Prematur" berawal dari penemuan ide yang berlanjut pada riset, kemudian mengamati karya-karya yang mempunyai kesamaan baik ide, tema, dan objek yang diangkat agar memperoleh hasil yang bisa dikatakan orisinal.

\section{Konsep Estetik}

Agus Sachari dalam bukunya Estetika mengatakan, di Indonesia, nilai-nilai estetik klasik memiliki keterkaitan dengan kedalaman rasa dan kehalusan budi, yang kemudian melahirkan kesantunan, kearifan, kebahagiaan, kemashlahatan, dan juga kesusilaan yang dijunjung tinggi. Masih dari sumber yang sama dijelaskan bahwa para pemikir estetika yang menekankan keluhuran budi, selalu berkaitan dengan proses pendidikan manusia untuk menjadi lebih baik dari sebelumnya, melalui proses penyadaran atau proses pembelajaran (2002:38).

Konsep estetis yang tertuang dalam tataran ideational karya "prematur" ini adalah menciptakan sebuah karya video seni dengan konten pesan dengan tujuan mendidik manusia untuk menjadi yang lebih baik, yaitu dengan memberikan kesadaran pada masyarakat mengenai fenomena ibu hamil yang merokok dan terpapar asap rokok yang mengakibatkan janin lahir prematur. Dalam karya premature ini pola ungkap pesan menggunakan konsep kausalitas yang dalam sistem tanda pada semiotika disebut indeks. Konsep kausalitas atau sebab akibat ini nantinya akan dibedah menjadi dua kanal video untuk penyajiannya sebagai bentuk makna instrumentalnya.

Pada tataran technical, berbagai teknik dapat digunakan untuk menghasilkan berbagai nilai estetika yang berbeda. Perangkat teknis menghasilkan berbagai ragam imaji dan kesan visual. Pemilihan angle, komposisi gambar dan penataan cahaya dapat didayagunakan untuk membentuk estetika visual dalam karya. 
Diterbitkan oleh Program Studi IImu Komunikasi

Universitas Ahmad Dahlan Yogyakarta

\section{Konsep Teknik}

Pada penciptaan karya hal teknis menjadi sangat penting karena menjadi penentu hasil akhir dari eksekusi sampai menjadi sebuah karya. Konsep teknis memberikan gambaran saat proses pra produksi dan proses produksi sehingga kualitas materi hasil eksekusi atau produksi bisa dihasikan secara maksimal.

a. Recording

Video dihasilkan dari perekaman direct recording berupa adegan live shot dengan konsep simple shot kamera statis. Kamera menggunakan lensa dengan fix focal length 50 mm untuk memberikan kesan adanya kedalaman dimensi pada objek walaupun background menggunakan warna solid.

b. Editing

Konsep editing pada dasarnya menggunakan continuity editing, karena pada karya ini adalah sebuah video dengan long shot. Sehingga dalam editing nantinya hanya akan dilakukan grading, colouring, dan penambahan animasi serta penyatuan audio.

c. Teknik Penyajian Karya

Penyajian dengan teknik dua kanal menjadi pilihan yang dirasa akanefektif mewujudkan konsep kausalitas ini. Memutar dua video dengan bantuan dua proyektor dan dua DVD player, berisi konten yang berbeda dengan timing waktu yang disamakan akan membentuk pesan secara utuh dan menciptakan pengalaman yang berbeda dari menonton video satu kanal pada umumnya. Sehingga penonton akan mendapatkan pengalaman audio visual yang baru tanpa meninggalkan tujuan dari karya ini yaitu memberikan informasi dan pengetahuan mengenai bahaya asap rokok yang dapat menyebabkan bayi prematur yang diharapkan nantinya membentuk sebuah social awareness.

\section{Video Art}

Video tumbuh independen, murni untuk mengekspresikan makna dan pesan, dari siapa saja. Namun kehadirannya sendiri kemudian memiliki efek yang sangat besar. Hal ini terlihat dari luasnya kemungkinan siapa saja yang mampu merepresentasikannya sebagai video seni. Sehingga terbukanya cakrawala baru dalam segi representasi. Pada praktiknya, karya rekaman video art ini kadang menjadi elemen seni instalasi atau seni rupa pertunjukkan. Krisna Murti menjelaskan sifat video terdiri dari 3 karakter:

a. Showing, menayangkan secara langsung (live/realtime),

b. Recording, video dapat berfungsi untuk perekaman yang berguna sebagai pelestarian (pembekuan) waktu, memori/histori dan data.

c. Editing, menyunting (memanipulasi) video, kondisi dimana kita bisa mengintervensi media.

Penggunaan salah satu dari ke tiga karakter di atas dalam seni video sudah bisa menghasilkan sebuah karya, sehingga penggunaan video tradisional tidak perlu lagi dilakukan.

Dalam seni video segala sesuatunya dibebaskan tanpa adanya batasan tertentu. Setiap individu dapat membuat karya seni video tergantung dari sudut pandang masingmasing. Dengan kata lain "seni video adalah ekspresi individu melalui respon terhadap sesuatu yang diamati”. (Krisna Murti, 2009:225). Dengan demikian seni video adalah 
segala bentuk olahan rasa dan daya pikir manusia yang merespon peristiwa di lingkungannya, sehingga memicu ide atau gagasan yang diwujudkan melalui persilangan medium suara, gerak, visual, dengan menggunakan perangkat digital sebagai media, sehingga menyentuh rasa dan daya pikir serta perilaku pencipta yang mendorong penonton untuk mengikuti karya.

"Berbeda dengan film, konsep video seni tidak terikat oleh waktu (durasi). Lev Manovich mengenalkan istilah loops untuk pengulangan sequence atau durasi utuh yang menghasilkan naratif baru" (Ibid,2009:186). Krisna Murti mengatakan bahwa tidak ada formula yang baku yang dapat diterapkan pada karya seni video karena masing-masing seniman akan menggunakan pengalaman dan pemikirannya untuk menentukan bentuk estetis dari karya mereka. (Krisna Murti, 2006:30).

"Citraan gambar bergerak melalui seni video mempersoalkan masalah konsepsi identitas yang terumus dalam sistem pikiran, serta kemampuannya mendorong partisipasi orang" (Krisna Murti, 2009:107). Dari pendapat tersebut dapat disimpulkan bahwa seni video adalah media berekspresi seniman melalui gambar bergerak yang mempunyai kemampuan mendorong publik untuk dapat berpartisipasi di dalamnya dalam bentuk perilaku atau pemikiran.

\section{Indeks}

Dalam semiologi Peirce sebuah tanda atau representamen adalah sesuatu yang bagi seseorang mewakili sesuatu yang lain dalam beberapa hal atau kapasitas. Sesuatu yang lain itu dinamakan sebagai interpretant dari tanda pertama, pada gilirannya mengacu pada obyek. Dengan demikian, sebuah tanda atau representamen memiliki relasi triadik langsung dengan interpretant dan obyeknya. Peirce mengklasifikasikan tipe tanda tersebut menjadi tiga, yang agaknya paling simple dan fundamental, yaitu ikon, indeks, dan simbol yang didasarkan atas relasi representamen dan obyeknya. (Peirce, 1086:8)

Menurut Kris Budiman Indeks adalah tanda yang memiliki keterikatan fenomenal atau eksistensial di antara representamen dan obyeknya. "Di dalam Indeks hubungan antara tanda dan obyeknyaa bersifat kongkret, aktual, dan biasanya melalui suatu cara yang sekuensial atau kausal”. (2011:20).

Dari dua teori diatas bisa disimpulkan bahwa tanda indeksikal merupakan bagian dari proses untuk memunculkan interpretant karena adanya hubungan kausal dan sekuensial. Adanya hubungan sebab akibat menghasilkan sebuah pesan atau makna. Dalam karya "Prematur" ini nanti akan menggunakan tanda indeksikal ke dalam karya melalui dua video yang berbeda yang menunjukkan adanya hubungan kausal sehingga muncul makna. 
Diterbitkan oleh Program Studi IImu Komunikasi

Universitas Ahmad Dahlan Yogyakarta

\section{B. Pembahasan}

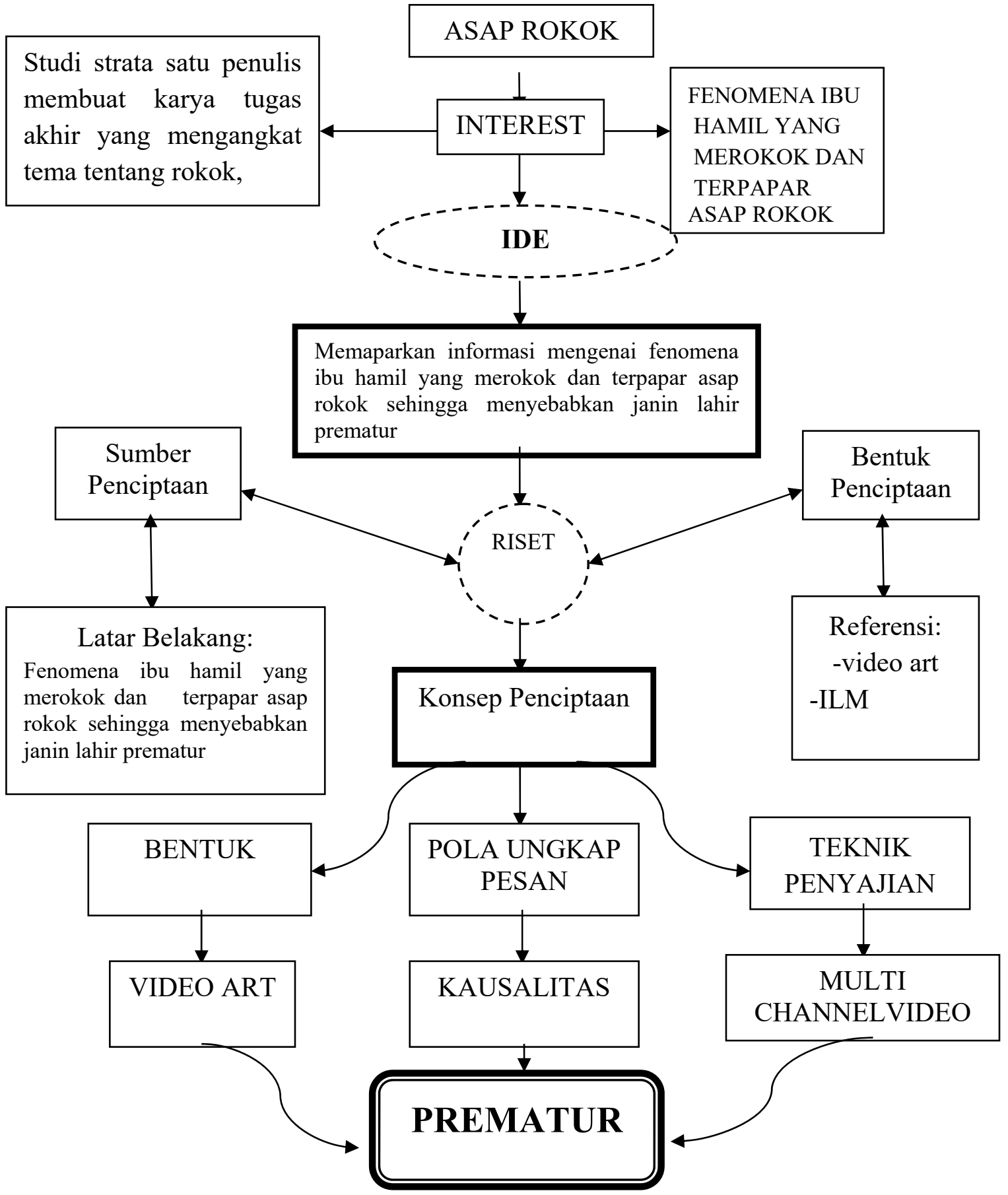

Gambar 1. Skema Metode Alur Penciptaan

Pengalaman dari kebiasaan merokok dan seringnya berbaur dengan lingkungan perokok baik laki-laki atau perempuan akhirnya tanpa disadari kebiasaan merokok menjadi hal yang biasa, merokok diruang tertutup bahkan merokok di tempat umum atau fasilitas publik. Sampai akhirnya saat menyelesaikan studi strata satu penulis membuat 
karya tugas akhir yang mengangkat tema tentang rokok, sehingga wacana dan isu tentang rokok dan yang bersinggungan dengan rokok menjadi bank data yang tersimpan di dalam diri penulis. Hal ini membentuk image tersendiri bahwa aktivitas merokok adalah aktivitas yang merugikan diri sendiri dan orang lain walaupun pada dasarnya aktivitas merokok dilindungi undang-undang, akan tetapi perokok juga harus memberikan hak-hak kepada yang tidak merokok untuk mendapatkan udara yang bersih dan bebas dari asap rokok. Image lain yang terseleksi adalah ketika berbincang dengan rekan yang sedang menempuh studi kedokteran di salah satu Universitas swasta di kota Jogja, sebuah fenomena yang merupakan fakta bahwa ibu hamil yang merokok dan terpapar asap rokok dapat menyebabkan janin lahir prematur. Hasil leburan image-image tersebut membentuk pra image yang merupakan sebuah kaitan kausalitas.

Fenomena ini sangat menimbulkan kegelisahan, sehingga ketika seni dan masalah berbaur menjadi satu, munculah sikap kreatif untuk mewujudkan pesan kritis melalui Penciptaan Karya Video Seni. Sebuah kegelisahan pribadi yang ingin dibagi dalam sebuah bentuk karya video seni agar timbul awareness bersama. Hal inilah yang kemudian menjadi ide dasar penciptaan sebelum dikembangkan menjadi bentuk penciptaan secara utuh.

Sebuah masalah didasari dari beberapa data-data yang terbentuk dari realita sosial. Sumber data sangat dibutuhkan untuk mendukung terciptanya karya yang kritis, karena di tahap ini akan banyak ditemukan banyak sebab akibat yang akan berpengaruh pada penggalian konsep ditahap berikutnya. Pengumpulan data termasuk tahap yang paling krusial, karena memang dari data-data itulah karya akan menjadi semakin dalam. Data-data yang didapatkan dari Pustaka, Mediaonline, wawancara, dan juga riset di beberapa instansi yang berhubungan dekat dengan obyek karya, yaitu ibu hamil, asap rokok, dan bayi prematur.

Proses eksperimen dibutuhkan dalam sebuah penciptaan karya seni. Eskperimen dilakukan sebagai salah satu cara agar tampilan visual dapat lebih berkembang, selain itu juga untuk lebih menguatkan ide kreatif yang akan di angkat untuk berkarya. Sebab dengan bereksperimen, kesatuan antara pengalaman dan insting berkarya akan membentuk pola pikir yang lebih terstruktur. Manusia terkait langsung dengan pengalaman dirinya secara langsung. Baik dari fenomena-fenomena hidup yang disadarinya maupun tidak disadarinya.

\section{Pra produksi}

Pada tahap ini ide ditransformasikan ke dalam sebuah naskah kemudian dijabarkan menjadi sebuah treatment. Treatment merupakan kerangka jabaran pesan yang akan dikemukakan sebagai panduan proses produksi, dan masih dimungkinkan terjadi pengembangan selama masih relevan dengan substansi. Dalam proses pra produksi ini persiapan lebih kepada hal-hal yang berhubungan dengan persiapan visual kemasan video yang akan dibuat. Dalam proses pra produksi ini perencanaan pengambilan gambar sangat direncanakan dengan matang karena penggunaan dua kanal membutuhkan ketelitian dan ketepatan agar tercipta kesinambungan yang saling mendukung.

Ketika proses-proses yang telah tersebut di atas dilalui maka akan muncul pemetaan dan pencatatan inventaris kematangan dari ide yang telah berbuah menjadi 
Diterbitkan oleh Program Studi IImu Komunikasi

Universitas Ahmad Dahlan Yogyakarta

bagian-bagian penting dari sebuah karya yang akan dibuat. Pemetaan ini antara lain dari aspek konsep naskah, visualisasi naskah (story board), tata kamera, tata cahaya, tata suara, dan tata artistik. Sehingga setelah dilakukan planning and prepare alat dari semua unsur tersebut maka karya siap untuk masuk tahapan produksi.

\section{Produksi}

Memasuki tahap produksi persiapan lebih mengarah pada manajemen lapangan dan juga kesinambungan antara konsep dengan eksekusi gambar yang harus dicermati secara detail saat pengambilan gambar. Setelah semua persiapan untuk kebutuhan visual sudah terkondisikan dengan baik, berikutnya yang harus di lakukan pada saat produksi adalah tentang manajerial lapangan. Seorang videomaker tidak saja berkutat dalam dalam konsep kekaryaan namun juga harus teliti saat proses pengambilan gambar di lokasi.

\section{Pasca produksi}

Proses ini merupakan tahap akhir atau penyempurnaan dalam memproses hasil shoting untuk diolah. Pengolahan atau editing yang dilakukan meliputi aspek suara dan gambar yang disesuaikan melalui penjabaran visual kasar terlebih dahulu. Pada pasca produksi elemen-elemen seperti data sound fx, dan ilustrasi musik dipersiapkan dan digabungkan menjadi kesatuan yang utuh. Semua hasil shoting di-transfer ke media digital atau disebut dengan capturing untuk persiapan editing oleh editor. Berikut adalah hal-hal yang dilakukkan selama proses pasca produksi berlangsung.

\section{Display Karya}

Penyajian dari karya ini adalah menggunakan 2 kanal. Dua video yang diputar secara bersamaan dengan timing yang sudah dirancang dengan matang dan dengan durasi yang sama. Pemutaran video menggunakan dua dvd player yang akan diproyeksikan langsung dengan proyektor pada masing-masing player dengan pemutaran teknik looping. Penataan proyektor adalah atas bawah.Video kanal pertama dibawah kanal kedua. Hal ini agar ada unsur kedekatan bahwa realitas asap yang selalu bergerak keatas. Dua video ini mempunyai relasi yang akan menuntun penonton untuk berinterpretasi. Proses ini merupakan proses akhir dari pembuatan karya. Insting dan kreatifitas dari seorang VideoMaker kembali digunakan untuk menyelaraskan, dan membuat keindahan dalam bentuk audio visual agar visi dan misi dari pembuatan karya ini dapat sesuai dengan target yang direncanakan.

\section{Pembahasan Karya}

Pada dasarnya proses penciptaan karya seni video ini secara keseluruhan hampir sesuai dengan metode yang diterapkan akan tetapi tetap terjadi kendala. Beberapa kendala teknis pada proses produksi menjadi tantangan yang merupakan bagian dari proses kreatif yang harus dihadapi dan dicari pemecahannya. Berikut ulasan karya dari video seni Prematur yang diuraikan dalam tiga segmen. 


\section{Segmen I}

\section{a. Video Kanal 1}

Visual

Di sebuah ruangan dengan pencahayaan siluet duduklah seorang wanita hamil dengan perutnya yang besar menghisap rokok. Beberapa kali menghisap rokok lalu menghembuskan asapnya keatas.

\section{Suara}

Musik: instrument piano lagu twinkle-twinkle little star

\section{Pembahasan}

Visual video pada kanal 1 ini adalah siluet wanita hamil yang sedang melakukan aktifitas merokok. Siluet digunakan sebagai maksud bahwa dalam video ini karakter wanita hamil tidak merujuk pada usia, suku, maupun ras tertentu. Karakter wanita hamil diterapkan secara utuh sebagai konvensi bahwa wanita hamil adalah berperut besar. Siluet dari sesosok wanita dengan perut yang besar dalam visual karya video ini mewakili dari setiap wanita hamil yang ada di dunia ini.

Siluet juga digunakan sebagai point of interest dalam video ini, sehingga penonton bisa mengintrepretasikan bahwa wanita wanita hamil dalam karya ini adalah tokoh tematik sehingga pesan yang akan dirangkai dalam karya video ini nantinya bisa lebih mudah diterima.

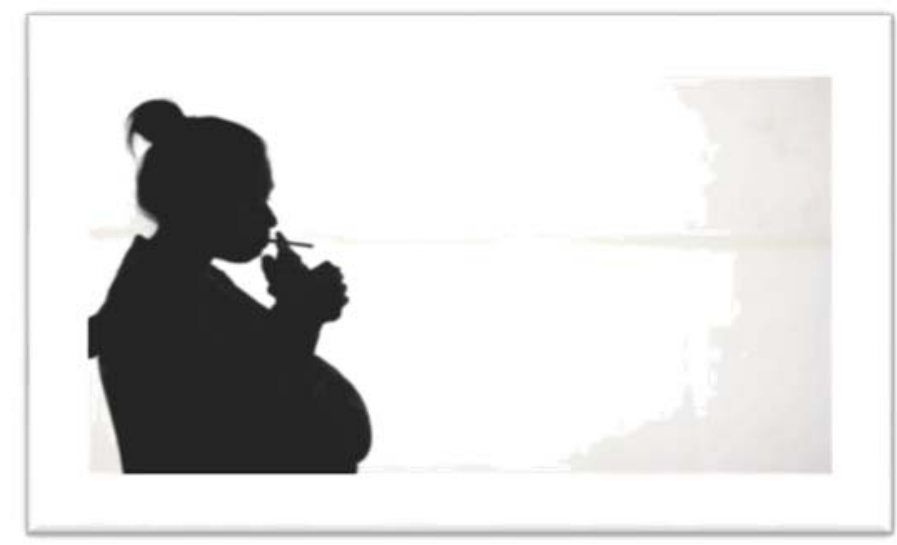

Gambar 2. Screenshot video kanal 1 segmen 1

\section{b. Video Kanal 2}

\section{Visual}

Terlihat empat tabung kaca transparan yang mengambang pada sebuah ruangan putih. Di dalamnya terlihat bayi yang berputar pelan.

\section{Audio}

Musik: Instrumen lagu Twingkle-twinkle little star

\section{Pembahasan}

Tabung kaca berbentuk oval sebagai representasi sebuah kandungan, didalamnya terdapat repro bayi berbentuk boneka menekankan bahwa gabungan boneka bayi dan tabung adalah bayi yang berada dalam kandungan. Gerakan memutar dengan pelan sebagai wujud dari pergerakan waktu dan menggambarkan bayi di dalam tabung tersebut 
Diterbitkan oleh Program Studi IImu Komunikasi

Universitas Ahmad Dahlan Yogyakarta

hidup. Ada empat tabung yang berisi boneka bayi dengan gender yang berbeda dimaksudkan untuk mewakili janin-janin bayi yang ada pada kehidupan nyata.

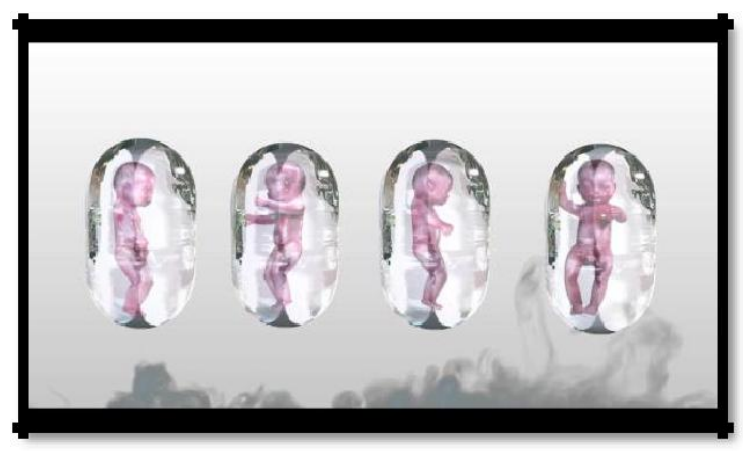

Gambar 3. Screenshot video kanal 2 segmen 1

\section{Segmen II}

\section{a. Video Kanal 1}

\section{Visual}

Siluet Wanita hamil yang merokok dengan background warna putih, disebelahnya berjajar 8 orang dengan masing-masing karakter dan gender yang sedang merokok. Perlahan asap tipis mulai memenuhi frame dan naik ke atas.

\section{Suara}

Soundeffect: suara bayi menangis, suara bayi tertawa, lantunan syair lagu twinkle twinkle little star dengan nuansa thriller.

\section{Pembahasan}

Musik: instrument piano lagu twinkle twinkle little star.

Pada segmen ini selain siluet wanita hamil dimunculkan 8 orang yang sedang merokok dengan masing-masing karakter dan gender, hal ini didasarkan dari fakta segmentasi perokok yang ada pada kehidupan sehari-hari. Masing-masing orang yang ditampilkan dalam video ini mewakili karakter dan gender perokok aktif yang ada.

Adegan yang dilakukan hanyalah merokok dengan natural tanpa ada cutting sampai satu batang rokok habis. Dari 8 orang ini akhirnya muncul cara menikmati rokok yang beragam dan tanpa dibuat-buat. Hal ini dimaksudkan sebagai pendekatan berupa slice of life untuk lebih mempermudah pesan sampai pada audience. Asap tipis yang kemudian muncul digunakan untuk menambah kesan dramatis dalam video ini sekaligus menguatkan aktifitas merokok yang ada di dalam frame. Secara lugas wanita hamil yang sebelumnya menjadi perokok aktif pada segmen ini terpapar asap rokok dari 8 orang perokok aktif.

Adanya 8 penokohan dimaksudkan sebagai pemaparan info mengenai fakta perokok aktif saat ini dilihat dari segi karakteristik usia, jenis kelamin, pekerjaan, dan umur. 


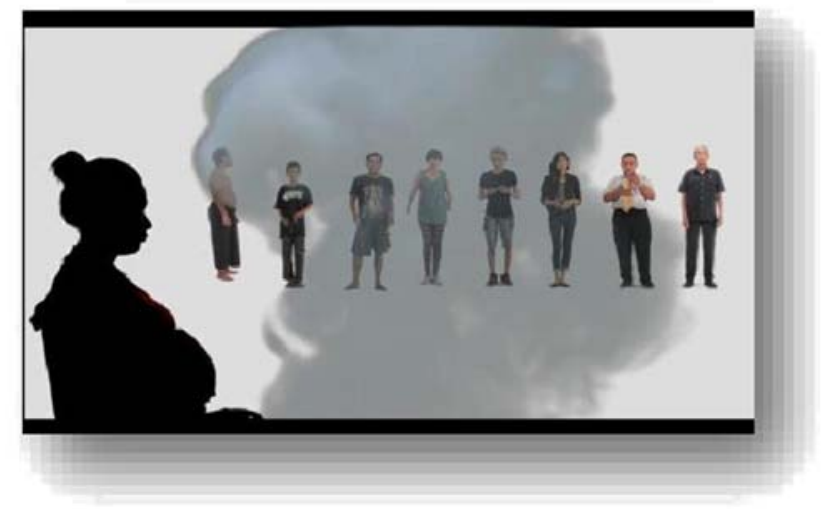

\section{b. Video Kanal 2}

Gambar 4. Screenshot video kanal 1 segmen 2

\section{Visual}

Perlahan asap yang masuk dari bawah mulai menyebar ke atas, tipis akantetapi menutupi hampir seluruh frame. Tabung yang berisi bayi masih berputar

\section{Audio}

Soundeffect: suara bayi menangis, suara bayi tertawa, lantunan syair lagu twinkle twinkle little star dengan nuansa thriller.

Musik: instrument piano lagu twinkle twinkle little star.

\section{Pembahasan}

Asap yang masuk pada kanal ini menjelaskan adanya hubungan sekuensial antara kanal 1 dan 2. Memberi kesan ada kesamaan waktu dan tempat, hal ini karena 2 kanal ini sebagai media untuk menerapkan tanda indeksikal atau kausalitas. Asap yang semakin banyak pada kanal ini diakibatkan pada kanal 1 ada banyak perokok.

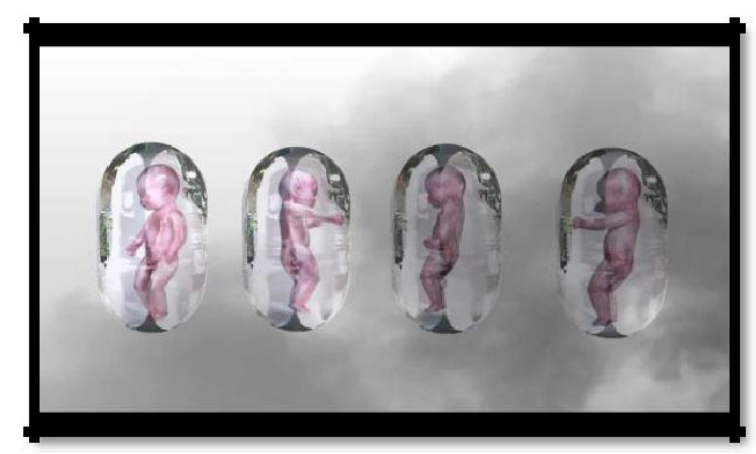

\section{Segmen III}

Gambar 5. Screenshot video kanal 2 segmen 2

\section{a. Video Kanal 1}

\section{Visual}

Siluet wanita hamil yang merokok dengan background warna putih, 8 orang yang merokok terduplikat semakin banyak. Perlahan asap tipis mulai menebal dan memenuhi frame sampai gelap lalu muncul shot bayi-bayi yang terjatuh dari kanal 2 . 
Diterbitkan oleh Program Studi IImu Komunikasi

Universitas Ahmad Dahlan Yogyakarta

\section{Suara}

Soundeffect: suara bayi menangis, suara bayi tertawa, lantunan syair lagu twinkle twinkle little star dengan nuansa thriller dan diakhiri dengan suarabenda tabung kaca yang pecah.

Musik: instrument piano lagu twinkle twinkle little star.

\section{Pembahasan}

Secara lugas wanita hamil yang sebelumnya menjadi perokok aktif pada segmen ini terpapar asap rokok dari banyak orang. Duplikat dari perokok aktif yang sebelumnya 8 orang menjadi titik klimaks dari segmen ini.

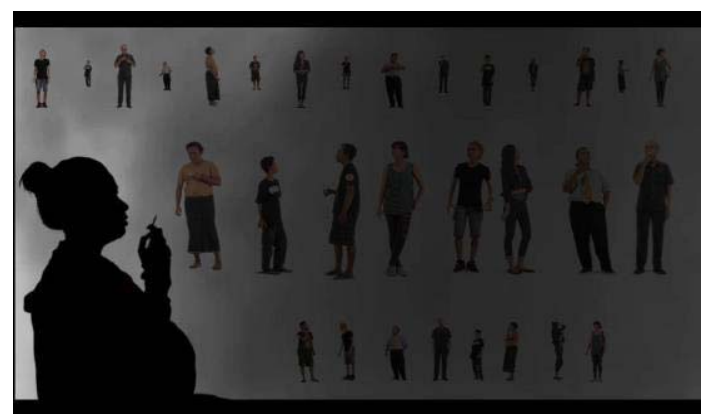

Gambar 6. Screenshot video kanal 1 segmen 3

\section{b. Video Kanal 2}

\section{Visual}

Asap semakin menebal hampir menutupi seluruh frame, dan satu persatu tabung yang berisi bayi jatuh.

\section{Audio}

Soundeffect: suara bayi menangis, suara bayi tertawa, lantunan syair lagu twinkle twinkle little star dengan nuansa thriller dan diakhiri dengan suaraBenda tabung kaca yang pecah.

Musik: instrument piano lagu twinkle twinkle little star.

\section{Pembahasan}

Secara lugas hal ini menyimpulkan dampak atau akibat dari apa yang terjadi di kanal 1. Bayi yang jatuh sebagai simbol bayi yang lahir prematur dan akhirnya tidak selamat. Kanal ini sebagai akibat yang ditimbulkan dari kanal 1.

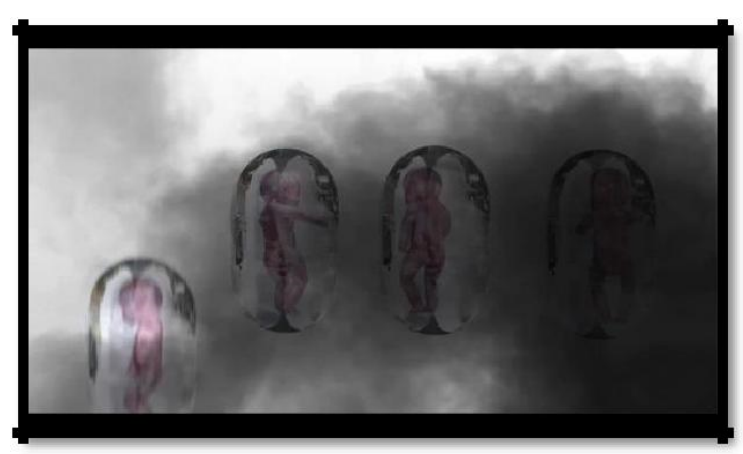

Gambar 7. Screenshot video kanal 2 segmen 3 


\section{PENUTUP}

Video seni prematur ini sebagai pemaparan dari fenomena Ibu hamil yang merokok dan terpapar asap rokok yang berdampak pada kelahiran janin prematur. Digunakannya video dua kanal menjadi media untuk membangun pesan dan informasi yang ingin disampaikan dari karya ini. Pendalaman isu yang diangkat menjadi modal kuat untuk mengekplorasi karya dengan pijakan kesadaran identitas, wacana, dan referensi seni yang kuat sehingga tidak terkesan coba-coba. Eksplorasi teknik dan eksplorasi estetis memungkinkan untuk memunculkan beberapa pilihan konseptual untuk mengeksekusi sebuah ide menjadi sebuah karya seni. Sehingga tidak menutup kemungkinan untuk menggabungkan beberapa disiplin ilmu untuk disatukan dalam sebuah karya.

Karya video seni Prematur ini sebagai sebuah output dari proses kreatif yang dipicu dari sebuah fenomena sosial yang terjadi disekitar kemudian respon sosial ini diwujudkan ke dalam sebuah karya video seni dengan melewati proses riset, eksplorasi, eksperimen dan metode penciptaan karya. Setelah melewati tahap ujian baik secara kekaryaan dan pertanggungjawaban karya secara tertulis ditemukan kekurangan pada peletakan proyektor pada kanal satu. Letak proyektor yang sejajar dengan mata membuat cahaya proyektor yang tembus dari screen mengganggu mata audience saat melihat karya. Solusi yang didapat dari kekurangan ini adalah menaikkan proyektor setinggi $10-20 \mathrm{~cm}$ dan mengarahkan ke bawah.

Kenaikan tinggi ini akan menjadikan proyeksi proyektor tidak simetris, sehingga perlu dilakukan setting manual display dan size yang ada pada menu pengaturan proyektor sehingga proyeksi dari proyektor menjadi simetris. Hal ini menjadi pembelajaran penting bagi penulis karena berkarya adalah proses belajar agar kedepannya karya yang dihasilkan bisa lebih baik lagi. Karya ini bukanlah akhir dari proses kreatif, karena tidak menutup kemungkinan akan dihasilkan karya-karya baru selanjutnya.

\section{DAFTAR PUSTAKA}

Aditama, T.Y. 2004,Sepuluh Program Penanggulangan Rokok. Majalah Kedokteran Indonesia, 54 (7):255-25.

Budiman, Kris. (2011),Semiotika Visual: Konsep, Isu, dan Problem Ikonisitas, Jalasutra, Yogyakarta.

Linda. (2011). Janin Yang Terpapar Nikotin. Diakses dari http://www.mediasari.com/2011/07/ancaman-rokok-bagi-wanita- hamil.html. dibuka tanggal 25 Maret 2015

Murti, Krisna. (2006), Apresiasi Seni Media Baru, Direktorat Kesenian, Direktorat Jendral Nilai Budaya Seni dan Film, Jakarta.

Murti, Krisna. (2009), Essay On Video Art and New Media, Indonesian Visual Art Archive, Yogyakarta.

Puryanto, Santoso, E.J., dan Sayono. 2012. Pengaruh Pendidikan Kesehatan terhadap Pengetahuan dan Sikap Siswa tentang Bahaya Mer-okok.Abstrak.Jurnal Penelitian Keperawatan. 
Diterbitkan oleh Program Studi IImu Komunikasi

Universitas Ahmad Dahlan Yogyakarta

Ross, S. (2006).Birth Right, Trans Media, Jakarta.

Sachari, Agus, 2002, Estetika, ITB, Bandung.

Sacharin, 1996.Prinsip Keperawatan Pediatrik.Jakarta: EGC 
